DOI: 10.2478/v10014-008-0014-5

Agrovoc descriptors: wild boar; wild animals; wildlife; damage; crop losses; browsing damage; fencing; electrical installations; plant protection; crop losses; zea mays

Agris category code: P01; H10

University of Ljubljana

Biotechnical Faculty

Department of Agronomy

\title{
Evaluation of different designs of temporary electric fence systems for the protection of maize against wild boar (Sus scrofa L., Mammalia, Suidae)
}

\author{
Matej VIDRIH ${ }^{1}$, Stanislav TRDAN ${ }^{2}$
}

Received July 2, 2008, accepted August 1, 2008.

Delo je prispelo 2. julija 2008; sprejeto 1. avgusta 2008.

\section{ABSTRACT}

Among free living animals in Slovenia, wild boar (Sus scrofa) damages agricultural land by rooting and primarily by directly feeding on open fields. In some areas of Slovenia this large wildlife animal causes more than $50 \%$ of all estimated damage to cultivated plants grown on arable and forage fields. Many techniques for controlling wild boar and preventing damage are known, but none of them is optimal. In a trial for preventing wild boar ingress into maize fields different designs of electric fence system were used. The trial in which we used an electric fence to prevent wild boar from entering a maize field was erected in the area of Šmihel near Postojna (Slovenia). We decided to erect the electric fence at the end of July, after the fertilization of the maize. The following designs of electric fence systems were used: 1 ) a plastic post with a polywire and two polytapes with spacings of 15,15 , and $30 \mathrm{~cm}$ between them; 2) a plastic post with polywire and a polytape with spacings 25 and $25 \mathrm{~cm}$ between them; 3 ) a steal post as a wire offset in an inverted $L$ shape on which three screws on rod insulators were fixed at a height of 15,30 , and $55 \mathrm{~cm}$ from the ground. A polytape at a height of $30 \mathrm{~cm}$ acted as depth and it was a so-called three-dimensional design of electric fence. No breaks through fencing were observed until the harvesting time of the maize for silage, although boar tracks on the outside of the fenced field were observed. Damage to arable fields in the vicinity of the protected field was also recorded.

Key words: fencing, damage prevention, protective measures, crop, wildlife management

\footnotetext{
1 Teach. Assist., Ph. D., Jamnikarjeva 101, SI-1111 Ljubljana, e-mail: matej.vidrih@bf.uni-lj.si

2 Assist. Prof., Ph. D., Jamnikarjeva 101, SI-1111 Ljubljana
} 


\section{IZVLEČEK}

\section{UČINKOVITOST RAZLIČNIH POSTAVITEV ZAČASNE ELEKTROOGRAJE PRI VAROVANJU KORUZNIH NJIV PRED DIVJIM PRAŠIČEM (Sus scrofa L., Mammalia, Suidae)}

Divji prašič (Sus scrofa) je $v$ Sloveniji pomembna prostoživeča vrsta. Škodo povzroča na kmetijskih zemljiščih, in sicer z ritjem in neposrednim hranjenjem. Na nekaterih območjih Slovenije predstavlja škoda po divjem prašiču več kot $50 \%$ vse s strani kmetov prijavljene škode. Ta je vezana tako na gojene kot samonikle rastline, namenjene za živež ali živalsko krmo. Za preprečevanje škode po divjem prašiču na poljščinah je znanih več načinov; ti pogosto niso dovolj učinkoviti, so predragi ali moteči pri oskrbi poljščin. Za preprečevanje vdora divjega prašiča na koruzno njivo smo $v$ našem poskusu uporabili začasno elektroograjo. Na območju Šmihela pri Postojni je bil izveden poskus varovanja posevka (silažne) koruze pred divjim prašičem od konca julija (zadnje dognojevanje) do spravila pridelka. Uporabljene so bile naslednje tri postavitve začasne elektroograje: 1) plastični količek z elektrovrvico in dvema elektrotrakoma z razmiki 15,15 in $30 \mathrm{~cm}, 2$ ) plastični količek z elektrovrvico in elektrotrakom z razmikoma 25 in $25 \mathrm{~cm}$, in 3) železni količek v obliki distančnika (številke 7) in višino vrvice/trakov 15, 30 in $55 \mathrm{~cm}$. Elektrotrak pri slednji postavitvi je na višini $30 \mathrm{~cm}$ deloval kot globina oziroma tretja dimenzija. Med poskusom vse do spravila pridelka ni prišlo do vdora divjih prašičev na ograjeni del zemljišča. Na zunanji strani ograje so bile opazne sledi divjega prašiča. Škoda zaradi preučevanega škodljivca je bila ugotovljena na sosednjih njivah, ki niso bile varovane.

Ključne besede: ograjevanje, preprečevanje škode, varstveni ukrepi, kmetijske rastline, upravljanje $z$ divjadjo

\section{1}

\section{INTRODUCTION}

In the opinion of farmers and hunters, wild boar (Sus scrofa L., Mammalia, Suidae) is the most damaging wildlife species, which in some areas of Europe and Slovenia cause more than $50 \%$ of the estimated damage to plants. Feeding and other activities of wild boar are very important reduction factors regarding the quantity and quality of cultivated and wild-growing plants (Schley and Roper, 2003). The damage which is done by wild boar on agricultural land often leads to disagreements between representatives of the local hunting association and farmers. The state is responsible for damage if the damage is spread over more than $50 \%$ of agricultural land and for damage which does not exceed this share, the regional hunting association which manages the hunting grounds where damage is noticed is obliged to pay compensation. In the opinion of many people, the solution lies culling a greater number of this wildlife species, which is more and more widespread in Europe. But experts are unanimous that it is not possible to improve the present situation only by means of harvesting.

Currently wild boar has colonized $55 \%$ of the territory of Slovenia and its potential habitat comprises $67 \%$ of the country. The distribution and number of wild boar will likely further increase, particularly if the present trends of environmental changes continue (increasing temperature, woodiness, reduction of coniferous trees) (Jerina, 2006). With regard to the mentioned problems, the question is raised of how farmers can protect their arable fields in a way which is friendy to animals, nature, and people, and which is effective and reliable enough and also economically justified since silage and grain maize represent the greater part of the feedstuffs on 
dairy and beef farms in Slovenia (Orešnik and Logar, 2001). Thus the yield loss of maize represents an additional problem to stock farmers, which forces them to purchase supplemental feed or diminishes the number of animals on their farms. Both solutions burden the farm budget and threaten its existence, even more so if the damage occurs over several consecutive years.

Until now farmers have used many different measures for damage prevention on cultivated or wild-growing plants due to wildlife species, namely conventional nonelectric wire (barbed, smooth, high tensile, woven) fences, either with different repellents (Boh et al. 1999) or intensive harvest throughout the year. More recently farmers have started to erect electric fences, which are a known tool for keeping farm animals enclosed while grazing (McKillop and Sibly, 1988) and which has shown promising results regarding preventing wild boar from entering fields (McKillop et al., 1992; Santilli and Stella, 2006). But the construction of permanent electric fences as one of a group of electric fences on small arable fields was not suitable with regard to other activities such as crop rotation, the migration of wildlife species during the non-vegetative period, and high building and maintenance costs.

With the aim of searching for proper solutions to preventing damage, in the year 2005 in an area of central Slovenia, we conducted a field experiment in which we tested different designs of temporary electric fencing in order to protect maize fields against wild boar. In the experiment we wanted to prove the effectiveness of temporary electric fencing with the intention to reduce damage due to wild boar. Additionally, we wanted to determine which such fence construction would be most cost effective and at the same time effective in preventing damage caused by wild boar.

The hunting ground, which is managed by the Hrenovice Regional Hunting Association, is a part of the Western High Karst hunting territory and it constitutes a border part of the territory. The area which is covered by Hrenovice Regional Hunting Association belongs to the Postojna administrative unit $\left(45^{\circ} 47^{\prime} \mathrm{N}, 14^{\circ} 13^{\prime} \mathrm{E}, 542 \mathrm{~m}\right.$ above sea level). The total area came to $4.915 \mathrm{ha}$ of which 4.786 ha is intended for hunting activities. The hunting ground includes a selfcontained population area of red deer (Cervus elaphus L.), chamois (Rupicapra rupicapra L.), mouflon (Ovis [orientalis] musimon Gmelin) and is the western part of the central population area of large carnivores in Slovenia.

\section{$2.2 \quad$ The field experiment}

We set up a field experiment in 2005 near the village Šmihel pod Nanosom (central Slovenia, $45^{\circ} 78^{\prime} \mathrm{N}, 14^{\circ} 22 \mathrm{E}^{\prime}, 581 \mathrm{~m}$ above sea level). We invited the Hrenovice Regional Hunting Association and a farmer whose arable fields were damaged in previous years by wild boar to participate. Namely, in the vicinity of the farmer's fields a stream, marsh, and more groves are located, which all offer wild boar good shelter.

In the experiment we fenced in an arable field on which wild boar have caused damage for many years. The size of the fenced in area was 12 hectares and an area of 1.5 hectares was unfenced and served as a control in the experiment. The damage which occurred on the latter area was evidence of wild boar presence in the observed terrain. Furthermore, damage to the meadows which surround the tested field provided evidence of wild boar presence. 
In order to determine the most appropriate temporary electric fence design we tested three types of construction: 1) a plastic post with a polywire and two polytapes with spacings of 15, 15 , and $30 \mathrm{~cm}$ between them as a three-strand fence design; 2) a plastic post with polywire and a polytape with spacings 25 and $25 \mathrm{~cm}$ between them as a two-strand fence design; 3) a steal post as a wire offset in an inverted $L$ shape on which three screws on rod insulators were fixed at a height of 15,30 , and $55 \mathrm{~cm}$ from the ground as a three-strand offset fence design (Figure 1).
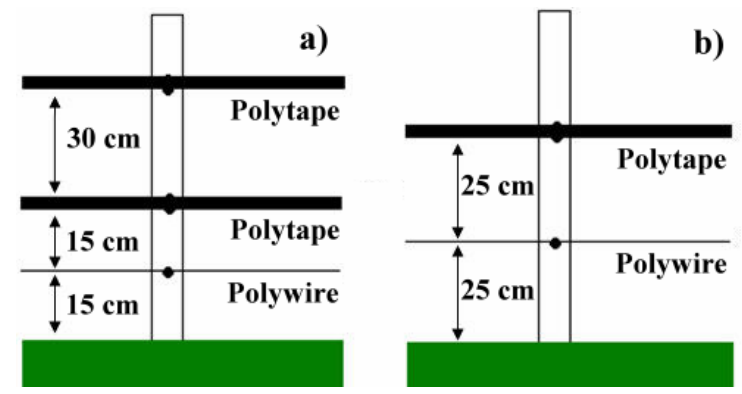

b)

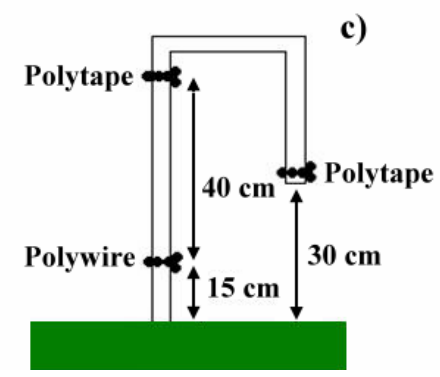

Figure 1: The three fence designs used in the experiment: a) a fence with two polytapes and a polywire, b) a fence with a polytape and a polywire (both front view), and c) an offset inverted $L$ shape fence with polytapes and a polywire (side view).

All lines were positively charged (hot) and were white to increase the likelihood of wild boar seeing them at night. The fences were powered by a Horizont energizer of 6 joules of stored energy, run on a battery of $55 \mathrm{Ah}$, as this was enough to maintain a sufficient voltage of $5.5 \mathrm{kV}$ in the strands. On the first strainer post we installed a lightning diverter because lightning can damage an energizer if it strikes the fence. On the fence we also mounted a livelite, a warning device that warns of fence operation, in this case as a flash each time a pulse of more than 2.5 $\mathrm{kV}$ was sent from the energizer to the wires. Shorting-out of the fence by vegetation growth was prevented, when necessary, by trimming along the fence line to create a clear strip about $50 \mathrm{~cm}$ wide. Fence maintenance and voltage checks were conducted weekly and batteries replaced when voltage fell below $3.5 \mathrm{kV}$.

We erected the electric fence designs on July 23 and this is also the date of our observations and at that time the maize was in the early milk stage. From a starting point we erected in both directions of the field all three fence designs. We conducted observations in 5 day intervals while checking if the fence voltage was adequate; if it was not, we changed the battery and wild boar tracks could be observed. We concluded the experiment when the owner harvested the crop for the silage (October 18). As an indication of wild boar presence in the vicinity of our experimental site, during the season a great deal of damage was caused to nearby meadows.

\section{3}

\section{RESULTS}

\subsection{The activity of wild boar on the plot and in the vicinity}

On the July 92005 we observed the first damage due to wild boar on a wheat field in the near vicinity of the experimental field. The field was protected with an acoustic diverting mechanism, but it looked like it did not work. On August 11 wild boar entered the maize field. According to the tracks, only piglets crossed the fence for a short time and sows stayed on the other side because there was no break in the fence, otherwise they would have followed the young due to maternal instinct.

We observed extensive damage to the grassland in the vicinity of the electric fence on August 15. Wild boar tracks were not found near the fence, but around $6 \mathrm{~m}^{2}$ of 
grass sward was rooted. On the September 2 we noticed damage on the maize field which served as a test field, and so was not protected. The extent of the damage to the maize field was $10 \mathrm{~m}^{2}$. Also a week later we noticed a significant amount of further damage to the unprotected surrounding maize fields and to the grassland and it lasted until the conclusion of the experiment. The only time wild boar tried to enter the maize field protected by electric fencing was on September 16. This happened on the section of two-strand fence design.

\subsection{Material used and a cost comparison of the three electric fence designs}

On the basis of the known facts regarding the differences between permanent and temporary electric fences (Conover, 2002) and the advantages which temporary electric fence designs have (Huygens and Hayashi, 1999), when erecting fencing around arable fields in the growing season, we wanted to further reduce the cost of erecting the latter by opting for a third design. Table 1 presents the type of material and its quantity and costs per hectare. The materials ranged from 87 to 110 euros per hectare or from 22 to 27 euro cents per meter, not including the price of the energizer. The third (three-strand offset) electric fence design appeared to be the least expensive also because a part of it can be manufactured at a farm workshop, i.e. steel posts and it can be more durable.

Table 1: Cost calculation of three temporary fence designs, without energizer

\begin{tabular}{lcccccc}
\hline & \multicolumn{2}{c}{ three-strand fence } & \multicolumn{2}{c}{ two-strand fence } & \multicolumn{2}{c}{ three-strand offset fence } \\
Material & Quantity & EUR & Quantity & EUR & Quantity & EUR \\
Polywire & $400 \mathrm{~m}$ & 9.58 & $400 \mathrm{~m}$ & 9.58 & $400 \mathrm{~m}$ & 9.58 \\
Polytape $(12.5 \mathrm{~mm})$ & $800 \mathrm{~m}$ & 38.36 & $400 \mathrm{~m}$ & 19.18 & $800 \mathrm{~m}$ & 38.36 \\
Plastic post & 50 pieces & 62.07 & 50 pieces & 62.07 & - & - \\
Steel post & - & - & - & & 50 pieces & 24.24 \\
Screw-on rod insulator & - & - & - & & 150 pieces & 15.00 \\
& \multicolumn{7}{c}{110.20} \\
\hline
\end{tabular}

\section{$4 \quad$ DISCUSSION}

During the experiment, no wild boar successfully raided a fenced-in field of maize. All three temporary electric fence designs were $100 \%$ successful in keeping wild boar from entering the maize field. Others have reported approximately similar results in studies and experiments when testing electric fences to exclude other wildlife species - Asiatic black bear (Ursus thibetanus G. Cuvier) (Huygens and Hayashi, 1999), Eurasian badger (Meles meles L.) (Poole et al., 2002), and red deer (Gasparik et al., 1993) from crop fields. However, the $100 \%$ fence effectiveness in our case can also be explained by the possibility that the wild boar bypassed our experimental field and found food on other unprotected crop fields, which also seemed to be the case in our study. We expected the third design (Goddard et al., 2001) to be the most efficient, as beside the characteristics of the former two designs 
it also has an additional characteristic, i.e. a third dimension (depth). And it has been known for some time (VerCauteren et al., 2006) that this fence design can reduce the possibility of all other wildlife species entering so-protected fields.

When erecting any kind of electric fence it is important to pay attention to some measures and also to keep the fence in good condition during the whole period of field protection. In particular, an opening between the ground and the first wire can present a chance for an animal to enter the field. As stated by those who have to a broader extent investigated damage on farmland caused by wildlife species which root into the ground (Geisser and Reyer, 2004; Herrero et al., 2006) than was carried out here, the methods which attempt to reduce the damage are intensive harvesting, supplemental food offers in the forest, and the installation of electric fences (Geisser and Reyer, 2004). Our experiment in central Slovenia verified that the last method works. The next step to have better control over damage caused by wild boar is to upgrade the three-strand offset design of the temporary electric fencing.

\section{ACKNOWLEDGEMENTS}

The authors would like to thank Uroš Benec, Franc Pirc (the owner of the experimental plot), and the Hrenovice Hunting Association for financial support and technical assistance. The experiment was performed according to current Slovenian laws concerning animal research ethics. This work is a part of program Animal health, environment and food safety No P4-0092 granted by Slovenian Research Agency.

\section{REFERENCES}

Boh B., Košir I., Knez E., Kukovič M., Škerlavaj V., Škvarč A. 1999. Effect of microencapsulation on the efficacy of deer and rabbit repellent Daphne. Int. J. Pest. Manag. 45: 297-303.

Conover M. 2002. Resolving human-wildlife conflicts: the science of wildlife damage management. Lewis Publisher, New York: 235 p.

Gasparik J., Hell P., Sabados K. 1993. The protection of maize against damage caused by hoofed game with the help of electric fencing. Folia Venat. 23: 89-98.

Geisser H., Reyer H.U. 2004. Efficacy of hunting, feeding, and fencing to reduce crop damage by wild boars. J. Wildl. Manage. 68: 939-946.

Goddard P.J., Summers R.W., Macdonald A.J., Murray C., Fawcett A.R. 2001. Behavioural responses of red deer to fences of five different designs. Appl. Animal. Behav. Sci. 73: 289-298.

Herrero J., Garcia-Serrano A., Couto S., Ortufio V.M., Garcia-Gonzales R. 2006. Diet of wild boar Sus scrofa L. and crop damage in an intensive agroecosystem. Eur. J. Wildl. Res. 52: 245-250.

Huygens O.C., Hayashi H. 1999. Using electric fences to reduce Asiatic black bear depredation in Nagano prefecture, central Japan. Wildl. Soc. Bull. 27,: 959-964. 
Jerina K. 2006. Effects of environmental factors on the wild boar (Sus scrofa L.) spatial distribution in Slovenia. Res. Rep. Biotech. Fac., Univ. Ljubl., Forestry and Wood Science and Technology 81:3-20 [Slovenian].

McKillop I.G., Sibly R.M. 1988. Animal behaviour at electric fences and the implications for management. Mammal Rev. 18: 91-103.

McKillop I.G., Phillips K.V., Ginella S.G.V. 1992 Effectiveness of two types of electric fences for excluding European wild rabbits. Crop Prot. 11: 279-285.

Orešnik A., Logar A. 2001 Seasonal impacts on the lactation curve course in dairy cows. Res. Rep. Biotech. Fac., Univ. Ljubl. - Zootechny 77, Supl. 31: 143-149.

Santilli F., Stella R.M. 2006 Electrical fencing of large farmland areas to reduce crops damage by wild boars Sus scrofa. Agric. Mediterr. 136: 79-84.

Poole D.W., McKillop I.G., Westeren G., Hancocks P.J., Packer J.J. 2002. Effectiveness of an electric fence to reduce badger (Meles meles) damage to field crops. Crop Prot. 21: 409-417.

Schley L., Roper T.J. 2003. Diet of wild boar Sus scrofa in Western Europe, with particular reference to the consumption of agricultural crops. Mammal Rev. 33: 43-56.

VerCauteren K.C., Lavelle M.J., Hygnstrom S. 2006. Fences and deer-damage management: a review of designs and efficacy. Wildl. Soc. Bull. 34: 191-200. 